\title{
A review of bronchiolitis obliterans syndrome and therapeutic strategies
}

Don Hayes Jr

\begin{abstract}
Lung transplantation is an important treatment option for patients with advanced lung disease. Survival rates for lung transplant recipients have improved; however, the major obstacle limiting better survival is bronchiolitis obliterans syndrome (BOS). In the last decade, survival after lung retransplantation has improved for transplant recipients with $\mathrm{BOS}$. This manuscript reviews BOS along with the current therapeutic strategies, including recent outcomes for lung retransplantation.
\end{abstract}

\section{Introduction}

Lung transplantation is a treatment option for patients with advanced lung disease or irreversible pulmonary failure. Despite advancements in surgical techniques, lung preservation, immunosuppression, and management of ischemia/reperfusion injury and infections, acute and chronic allograft rejection continues to be a major problem. The incidence and severity of acute rejection in lung transplantation exceeds all other solid organ transplants $[1,2]$. Chronic rejection, more commonly called bronchiolitis obliterans syndrome (BOS), is the leading cause of death beyond the first year post lung transplantation $[3,4]$. The key clinical feature of BOS is the development of airway obstruction with a reduction of forced expiratory volume in 1 second $\left(\mathrm{FEV}_{1}\right)$ that does not respond to bronchodilators (Table 1) $[5,6]$. The hallmark histological findings of chronic rejection is obliterative bronchiolitis $(\mathrm{OB})$, which is an inflammatory process affecting small noncartilagenous airways $[7,8]$. Figure 1 is representative of the typical findings of OB histopathologically. The development of BOS is rare within the first year after lung transplant, but the cumulative incidence ranges from 43 to $80 \%$ within the first five years of transplantation [4,9-11].

\section{Diagnosis}

The diagnosis of BOS is typically made by clinical, physiological, and radiographic parameters. Due to the sporadic or patchy involvement of $\mathrm{OB}$, pathologic

\footnotetext{
Correspondence: Don.Hayes@nationwidechildrens.org
}

The Ohio State University Columbus, OH, USA diagnosis can be missed by transbronchial biopsies (TBB) [5], which are often performed to exclude other diagnoses including acute rejection or infection. Histologically, early lesions of BOS demonstrate submucosal lymphocytic inflammation and disruption of the epithelium of small airways, followed by an ingrowth of fibromyxoid granulation tissue into the airway lumen, resulting in partial or complete obstruction. Subsequently, granulation tissue organizes in a cicatricial pattern with resultant fibrosis and thus obliterates the airway lumen [12]. In some instances, the only residual histologic evidence of BOS is a ring of circumferential elastin around an otherwise undetectable airway, what is termed the "vanishing airways disease" [12].

As a result of histologic variability, the International Society for Heart and Lung Transplant (ISHLT) developed standard nomenclature and made a distinction between documented $\mathrm{OB}$ and BOS [13]. An ad hoc working group was established under the auspices of the ISHLT for the purpose of developing a clinically applicable system and published their original recommendations in 1993 [13]. The group concluded that the FEV was the most reliable and consistent indicator of allograft dysfunction, excluding other identifiable causes with the adoption of the term BOS to describe such dysfunction, recognizing that there may or may not be pathologic evidence of $\mathrm{OB}$ present [13]. The group also defined 4 stages of BOS, each with 2 subcategories to indicate whether pathologic evidence of $\mathrm{OB}$ had been identified [13].
C Biomed Central

(C) 2011 Hayes; licensee BioMed Central Ltd. This is an Open Access article distributed under the terms of the Creative Commons Attribution License (http://creativecommons.org/licenses/by/2.0), which permits unrestricted use, distribution, and reproduction in any medium, provided the original work is properly cited. 
Table 1 Bronchiolitis obliterans syndrome (BOS) classification

\begin{tabular}{cc}
\hline BOS Stage & Classification \\
\hline 0 & $\mathrm{FEV}_{1}>90 \%$ of baseline $\& \mathrm{FEF}_{25-75 \%}>75 \%$ of baseline \\
\hline $0-\mathrm{p}^{*}$ & $\mathrm{FEV}_{1}$ 81-90\% of baseline \&/or $\mathrm{FEF}_{25-75 \%} \leq 75 \%$ of baseline \\
\hline 1 & $\mathrm{FEV}_{1}$ 66-80\% of baseline \\
\hline 2 & $\mathrm{FEV}_{1} 51-65 \%$ of baseline \\
\hline 3 & $\mathrm{FEV}_{1} \leq 50 \%$ of baseline \\
\hline${ }^{* 0-p}=$ potential BOS, Modified from Reference \#6
\end{tabular}

The clinical course of BOS can vary from insidious onset and gradual decline in pulmonary function over months to years to abrupt onset with severe decline in pulmonary function over a few weeks [14-16]. The clinical diagnosis of BOS requires a sustained pulmonary decline with a reduced $\mathrm{FEV}_{1}$ for more than 3 weeks and the exclusion of acute allograft rejection, anastomotic complications or stricture, infection, or other disease affecting pulmonary function. In comparison, acute allograft rejection is defined as perivascular or peribronchial mononuclear inflammation that may be associated with

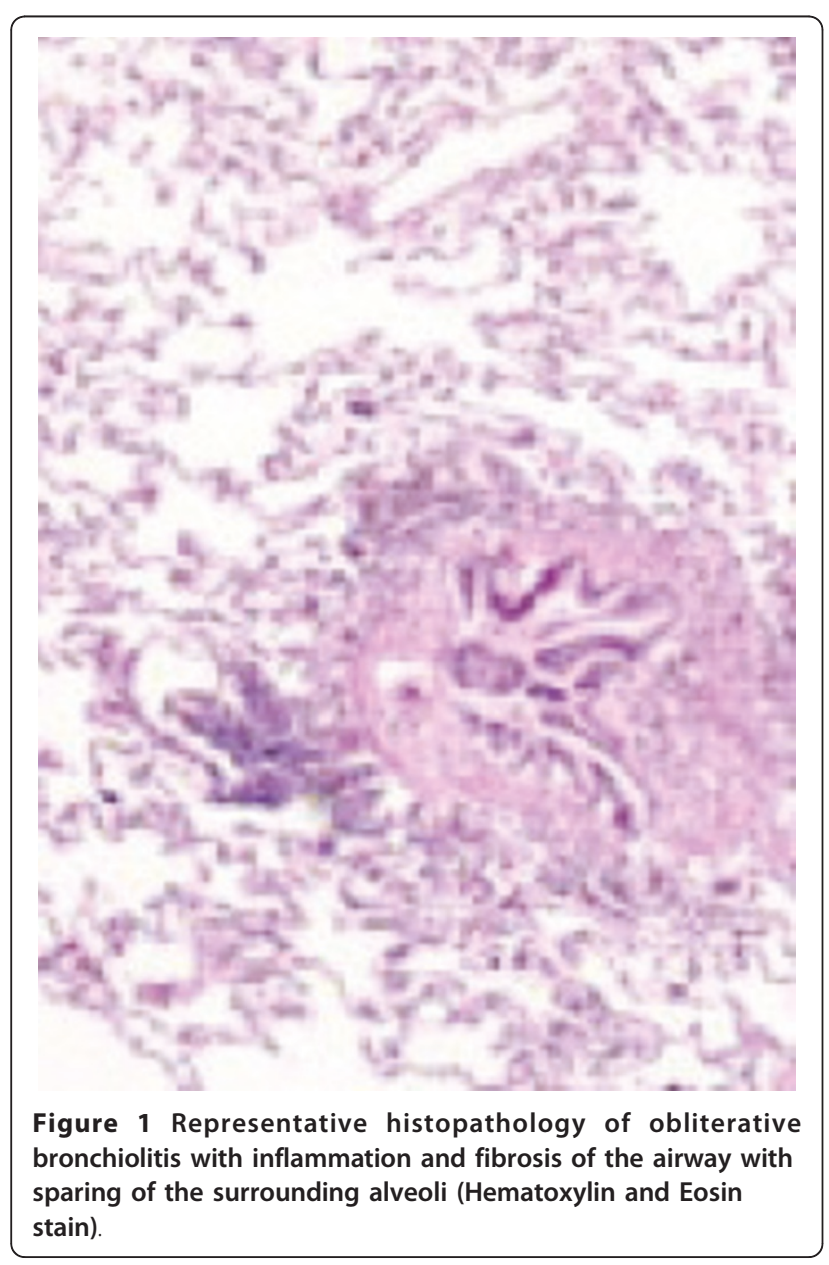

an acute reduction in pulmonary function. Clinical presentation of acute allograft rejection may vary from asymptomatic patients with acute rejection found on surveillance biopsy to non-specific symptoms including cough, dyspnea, sputum production, fever, hypoxia, and adventitious sounds on lung auscultation $[8,15]$. The current classification of BOS is based on changes in $\mathrm{FEV}_{1}$ with the maximum post-transplant $\mathrm{FEV}_{1}$ being assigned a $100 \%$ predicted value (the mean of the two best postoperative $\mathrm{FEV}_{1}$ values with at least 3 weeks between the measurements) and the reduction in the mean forced expiratory flow during the middle half of the forced vital capacity $\left(\mathrm{FEF}_{25-75 \%}\right)$ used as an early marker for BOS or potential BOS [5]. The current ISHLT classification system for BOS is outlined in Table 1.

Currently, radiographic imaging is not used as a diagnostic tool in transplant recipients when evaluating for BOS; however, high resolution computed tomography (HRCT) imaging with inspiratory and expiratory views may be helpful when considering the diagnosis. Numerous abnormalities may be seen including hyperlucency or air-trapping, bronchiectasis, thickening of septal lines, mosaic pattern of attenuation, or tree-in-bud pattern [17]. Obtaining an expiratory CT scan may help reveal air-trapping that is not evident on inspiratory scans in BOS $[17,18]$. Furthermore, the extent of air-trapping may correlate with BOS severity [18].

\section{Pathogenesis and Risk Factors for BOS}

The pathogenesis of BOS is complex and involves both alloimmune and non-alloimune mechanisms that occur alone or in combination. Chronic rejection is classified pathologically as either chronic vascular rejection or chronic airway rejection [7]. Chronic vascular rejection, the less common manifestation of rejection, involves the development of atherosclerosis in the pulmonary vasculature [7]. Chronic airway rejection, which is defined as OB histologically, is seen more frequently and results in increased morbidity and mortality $[7,19]$. Table 2 summarizes the current reported risk factors associated with the development of BOS in lung transplant recipients. The major risk factors associated with BOS are reviewed in the following paragraphs.

\section{Acute rejection}

Acute rejection is well defined as a primary risk factor in the development of BOS [9,20-25]. Recurrent, late, and severe episodes of acute rejection have all been associated with an increased risk for BOS. Moreover, Hachem et al [26] recently demonstrated that a single episode of minimal acute rejection without recurrence or progression to a higher grade of rejection was a significant predictor of BOS independent of other risk factors. 
Table 2 Risks factors for bronchiolitis obliterans syndrome after lung transplantation.

\begin{tabular}{cc}
\hline Probable & Potential \\
\hline Acute rejection & Aspergillus colonization of the lower airways \\
\hline CMV pneumonitis & Aspiration \\
\hline HLA-mismatching & CMV infection (without pneumonitis) \\
\hline Lymphocytic bronchitis/bronchiolitis & Donor antigen-specific activity \\
\hline Noncompliance with medications & Epstein-Barr virus reactivation \\
\hline Primary graft dysfunction & Etiology of native lung disease \\
\hline & Gastroesophageal reflux \\
\hline & Older donor age \\
\hline
\end{tabular}

\section{Pneumonia/Airway colonization}

Pneumonia and/or airway colonization with gram positive and gram negative pathogens as well as fungi are independent determinants of chronic allograft dysfunction [27]. In an interesting study, serology to Chlamydia pneumoniae in donors and recipients was associated with the development of BOS in lung transplant recipients. In fact, BOS occurred more frequently and earlier in C. pneumoniae seropositive donors, and the reverse was true in seronegative recipients [28]. In another study, colonization of the lower airways with Aspergillus was also determined to be a potential causative role for the development of BOS post-lung transplantation [29]. Exudative bronchiolitis, as determined by HRCT imaging, was associated with an increased risk of BOS in lung transplant recipients [30].

\section{Type of transplant}

The type of transplant, whether single or bilateral, may be a risk factor for the development of BOS. In a retrospective review of 221 lung transplant recipients with chronic obstructive pulmonary disease (COPD), bilateral transplant recipients were more likely to be free of BOS than single recipients three years (57.4\% vs $50.7 \%)$ and five years $(44.5 \%$ vs $17.9 \%)$ after transplantation ( $\mathrm{P}=$ $0.024)$ [31].

\section{Viral infection}

Lower respiratory tract infections due to community acquired respiratory viruses have been reported to increase the risk for BOS, including rhinovirus, coronavirus, respiratory syncytial virus, influenza A, parainfluenza, human metapneumovirus, and human herpes virus-6 [32-35]. Therefore, treatment of these viral infections theoretically may reduce the incidence of BOS, but data are limited [36]. Cytomegalovirus (CMV) infection has also been well described as a potential risk factor in the development of BOS; $[19,37,38]$ however, one study demonstrated that histopathologically confirmed CMV pneumonia treated with ganciclovir was not a risk factor for BOS or patient survival nor was any particular CMV serologic donor/recipient group [39]. The treatment of CMV and the subsequent prevention of BOS remains unclear. In a more recent study, Epstein-Barr virus (EBV) reactivation detection by repeated EBV DNA analysis of blood in lung transplant recipients was associated with the development of BOS [40].

\section{Primary graft dysfunction}

Ischemia-reperfusion injury after lung transplantation or primary graft dysfunction was associated with the later development of BOS [41-43]. Daud et al [43] reported that out of 334 lung allograft recipients, 269 had primary graft dysfunction: 130 had grade 1, 69 had grade 2 , and 70 had grade 3 . A multivariable model demonstrated that the increased risk for BOS with primary graft dysfunction was independent of acute rejection, lymphocytic bronchitis, and community-acquired respiratory viral infections [43]. Furthermore, this increased risk of BOS was directly related to the severity of primary graft dysfunction [43].

\section{Gastroesophageal reflux}

Gastroesophageal (GE) reflux is very common post-lung transplant and may contribute to chronic allograft rejection. The mechanism by which GE reflux contributes to BOS remains unclear. The presence of bile acids and pepsin in bronchoalveolar lavage (BAL) fluid from lung transplant recipients suggests that aspiration may elicit airway injury $[44,45]$. Moreover, treatment with proton pump inhibitors reduced acid reflux but did not affect nonacid reflux, including bile or pepsin, suggesting the presence of these elements in the lower airways as factors associated with BOS [45]. Early surgical treatment of GE reflux with fundoplication after lung transplantation has been associated with greater freedom from BOS 
and has improved survival [46,47]. A single institution study reported that $93 / 128$ (73\%) of lung transplant recipients had abnormal ambulatory 24-hour esophageal $\mathrm{pH}$ probe results [46]. After fundoplication, 16 patients had improved BOS scores, with 13 of these patients no longer meeting the criteria for BOS [46]. Another small study demonstrated that early aggressive surgical treatment of GE reflux with fundoplication not only improved rates of BOS but also survival [47].

\section{Human leukocyte antigen mismatches}

The effect of human leukocyte antigen (HLA) mismatches upon the development of BOS has been reported but remains controversial. The development of anti-HLA class I and II antibodies was associated with BOS $[15,48,49]$. Furthermore, an association between BOS and mismatches at the A locus [21,50], two DR mismatches [51], or total mismatches at the A locus, B locus, or DR locus $[9,50]$ are reported. However, mismatches at the HLA A locus but not the B locus were associated with acute cellular rejection but not BOS [52]. Further research is needed to investigate this very important issue.

\section{Autoimmunity}

An emerging concept regarding BOS is the possibility of autoimmunity rather than alloimmunity to hidden epitopes of collagen type V. These epitopes are exposed as a result of ischemia and reperfusion injury or other insults that may damage the respiratory epithelium [53]. Further research is ongoing to investigate these important findings.

\section{Therapies for BOS}

\section{Immunosuppressant therapy}

A small number of studies have assessed the different therapeutic modalities that are reportedly beneficial in these patients. Adjustments in immunosuppressant therapy and the use of immunomodulating medications are potential therapeutic options. Adjustments in the immunosuppressive agents have demonstrated some positive outcomes [54-58]. Cairn et al [54] reported that the conversion of cyclosporine to tacrolimus stabilized spirometric measurements in patients with BOS while Whyte et al [55] demonstrated similar results with the introduction of mycophenolate mofetil. In one study, BOS was less likely to progress when sirolimus was substituted for azathioprine in 37 lung transplant recipients receiving cyclosporine or tacrolimus, but the sirolimus had to be discontinued due to side effects [56].

\section{Novel or emerging therapies}

The use of other immunosuppressant therapies in novel ways may improve outcomes for BOS. There is evolving research in the use of aerosolized cyclosporine [59-61]. A single-center, randomized, double-blind, placebo-controlled trial of aerosolized cyclosporine was performed with initiation of the drug within six weeks after lung transplant along with routine systemic immunosuppression [59]. Aerosolized cyclosporine did not improve the rate of acute rejection but improved survival and extended periods of chronic rejection-free survival [59]. More recently, a single center randomized study demonstrated improvement in the pulmonary function of lung transplant patients who received aerosolized cyclosporine for the first 2 years after transplantation compared to placebo [60]. A recent case report demonstrated that aerosolized tacrolimus was associated with improvement in both functional capacity and oxygenation in a patient with BOS [62]. There are other therapies under investigation, including alemtuzumab, an anti-CD 52 antibody, which significantly improved the histological grade of BOS in 7 of 10 patients but had no impact on pulmonary function in an open label study [63].

\section{Azithromycin therapy}

Azithromycin displays immunomodulatory effects that seem to be beneficial in several pulmonary disorders, including BOS. Three studies showed the value of prolonged azithromycin ( $250 \mathrm{mg}$ orally every other day) in a total of 34 patients with BOS with an improvement in the $\mathrm{FEV}_{1}$ for some patients but not all [64-66]. In a larger observational study, Gottlieb et al [67]. demonstrated that 24/81 (30\%) patients with BOS had improvement in the $\mathrm{FEV}_{1}$ after 6 months of azithromycin therapy; 22 of the 24 responders improved after only 3 months of therapy. With univariate analysis, azithromycin responders at 6 months demonstrated higher pretreatment BAL neutrophils [67]. Neurohr et al [68] also demonstrated that BAL neutrophilia in stable lung transplant recipients had a predictive value in the identification of BOS.

\section{Statin therapy}

Statins (3-Hydroxy-3-methylglutaryl coenzyme A reductase inhibitors) are widely used lipid lowering agents that have demonstrated immunomodulatory effects. The 6-year survival of lung transplant recipients receiving statin therapy was much greater than patients not on statin therapy [69]. Acute rejection was less frequently found in the statin group; none of the 15 recipients started on statin therapy during the first postoperative year developed $\mathrm{OB}$, whereas the cumulative incidence among control subjects was $37 \%$.

\section{Extracorporeal photopheresis}

There is evidence that extracorporeal photopheresis is an effective method of treatment of any inflammatory 
disorder that is T-cell dependent, including BOS. In the late 1990's, two studies demonstrated the stabilization of airway obstruction due to BOS with extracorporeal photopheresis in $4 / 5$ patients [70] and $5 / 8$ patients [71], respectively, without complications occurring from the procedure. In fact, Salerno et al [71] reported 2 patients having histologic reversal of rejection. Functional stabilization was observed in $3 / 5$ patients with BOS that was accompanied by a slight increase or stabilization of the number of peripheral blood CD4(+)CD25(high) cells with in vitro features of Treg cells while the other 2 non-responsive patients with BOS showed a decline in the peripheral Treg subset [72]. An animal study further confirmed that CD4(+)CD25(+) T cells appears to play a key role in the immunomodulatory effects of extracorporeal photopheresis [73]. Over a 10-year period, one study reported that 12 patients with BOS treated with extracorporeal photopheresis had significant improvement in the decline in $\mathrm{FEV}_{1}, 112 \mathrm{~mL} / \mathrm{month}$ before therapy and $12 \mathrm{~mL} / \mathrm{month}$ after 12 cycles of therapy ( $\mathrm{P}$ $=0.011$ ) [74]. The effect of extracorporeal photopheresis on absolute $\mathrm{FEV}_{1}$ on the group of 12 patients was not significant and the therapy was tolerated [74].

More recently, 60 lung transplant recipients experienced a reduction in the rate of decline in lung function associated with progressive BOS with extracorporeal photopheresis therapy [75]. The decline in $\mathrm{FEV}_{1} 6$ months prior to treatment with extracorporeal photopheresis was $116.0 \mathrm{~mL} / \mathrm{month}$, but the slope decreased to $28.9 \mathrm{~mL} /$ month during the 6 -month period after initiation of therapy with the mean difference in the rate of decline being $87.1 \mathrm{~mL} /$ month $(\mathrm{P}<0.0001)$ [75]. Furthermore, the $\mathrm{FEV}_{1}$ actually improved in $25.0 \%$ of patients after starting extracorporeal photopheresis with a mean increase of $20.1 \mathrm{~mL} / \mathrm{month}$ [75].

\section{Management Strategies in BOS}

An important therapeutic strategy in treating BOS is initial prevention and aggressive treatment of known associated factors, as well as early identification of BOS in order to immediately begin available therapies. Initially, the clinical management of these patients should focus on risk reduction of primary graft dysfunction by decreasing mechanical ventilation time for donors and reducing allograft ischemia time, while also limiting cardiopulmonary bypass and blood product transfusions during transplantation [76].

Routine screening to define the onset of BOS is very important as there appears to be a therapeutic window for some of the treatment options available. Jain et al [77] demonstrated that azithromycin treatment initiated before the development of BOS stage 2 was independently associated with a significant reduction in the risk of death. Thus, clinicians should be closely monitoring lung transplant recipients, carefully monitoring for early chronic rejection. Spirometry should be performed routinely on lung transplant recipients, looking for any changes in the $\mathrm{FEV}_{1}$ and $\mathrm{FEF}_{25-75 \%}$ measurements based on the ISHLT classification system (Table 1). The use of HRCT imaging with inspiratory and expiratory views of the chest to assess for airtrapping may be helpful based on initial studies $[18,78]$, but further research is less conclusive regarding its value [79-81]. Currently, radiographic imaging remains supportive in the diagnostic evaluation and management of BOS. Figure 2 demonstrates the usefulness of HRCT imaging in diagnosing BOS in a 55 year-old patient who underwent right single lung transplantation in 1992 for alpha-1-antitrypsin deficiency but suddenly developed a $25 \%$ reduction in $\mathrm{FEV}_{1} 3$ years after undergoing single left lung transplantation for BOS. The right allograft clearly had significant bronchiectasis due to long-standing BOS, but the more recent allograft on the left side had signs of bronchiectasis with airtrapping, further supporting the diagnosis of BOS in that allograft.

Aggressive treatment of GE reflux, avoidance of infection, and timely vaccinations are instrumental in managing lung transplant recipients. Experimental risk factors reported in BOS should be considered from a clinical standpoint during the evaluation of transplant recipients, including higher bronchoalveolar (BAL) neutrophilia and IL-8 levels [82,83] as well as airway colonization with Pseudomonas aeruginosa [84,85]. Further research is

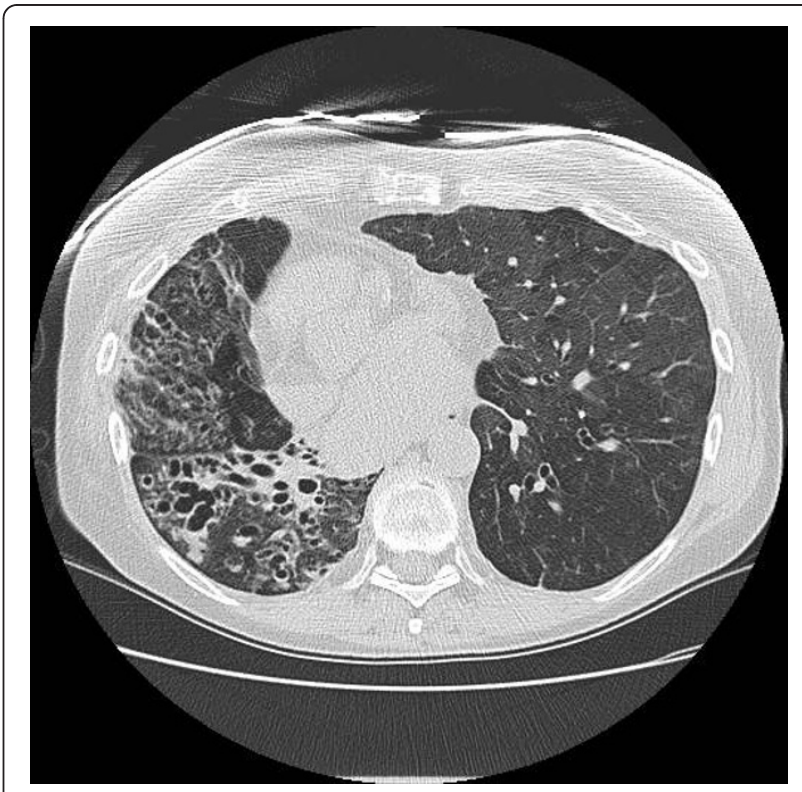

Figure 2 High resolution CT scan of the chest demonstrating bilateral bronchiectasis (right more severe than left) in a patient who underwent right single lung transplantation in 1992 for alpha-1-antitrypsin deficiency and left single lung transplantation in 2003 for bronchiolitis obliterans syndrome. 
Table 3 Lung retransplantation for bronchiolitis obliterans syndrome.

\begin{tabular}{|c|c|c|c|c|}
\hline First Author & Mean Age (years) & Number of Patients & Survival & Citation \\
\hline Brugière et al & 50 & 15 & $\begin{array}{l}60 \% \text { (1-year) } \\
53 \% \text { (2-year) } \\
45 \% \text { (5-year) }\end{array}$ & 73 \\
\hline Martinu et al & 40 & 12 & 75\% (1-year) & 74 \\
\hline Strueber et al & 42 & 37 & $\begin{array}{l}78 \% \text { (1-year) } \\
62 \% \text { (5-year) }\end{array}$ & 75 \\
\hline Aigner et al & 36 & 19 & $\begin{array}{l}72 \% \text { (1-year) } \\
61 \% \text { (5-year) }\end{array}$ & 76 \\
\hline Osaki et al & 44 & $12^{*}$ & $\begin{array}{l}67 \% \text { (1-year) } \\
67 \% \text { (2-year) } \\
44 \% \text { (5-year) }\end{array}$ & 77 \\
\hline
\end{tabular}

*1 patient underwent retransplantation twice

needed to better define the clinical role of these evolving factors.

\section{Retransplantation for BOS}

The definitive treatment for BOS and resulting bronchiectasis is retransplantation. However, lung retransplantation remains very controversial due to limited organ availability and lower survival rates as compared to initial transplants. In 1995, Novick et al [86] reviewed the records of 72 patients who underwent retransplantation for BOS at 26 North American and European centers. In this cohort, the actuarial survival rates were $71 \%$ at 1 month, $43 \%$ at 1 year, and $35 \%$ at 2 years [86]. For the 90 -day postoperative survivors, $63 \%$ were alive 2 years after retransplantation [86]. Further study in larger cohorts of 139 retransplant recipients in 1995 and 230 retransplant recipients in 1998 demonstrated very similar survival statistics $[87,88]$. Although survival rates for lung retransplantation were lower than survival rates for initial transplants, lung retransplantation continued to be performed in recipients who developed BOS. More recently, survival rates after lung retransplantation have improved [89-94]. A retrospective cohort study of 205 patients who underwent lung retransplantation between January 2001 and May 2006 in the United States demonstrated a 1-year survival of $62 \%$, 3-year survival of $49 \%$, and 5-year survival of $45 \%$ [89]. These authors did not assess the outcomes of patients undergoing retransplantation specifically for BOS, but there was definite improvement in outcomes for all patients after lung retransplantation in the modern era. Moreover, there have been smaller studies that have addressed the survival of lung retransplantation for BOS in adult patients; Table 3 outlines these research studies published since 2000. These 5 recent studies report 1 -year and 5 -year survival rates at $60-75 \%$ and $44-62 \%$, respectively in comparison to the current unadjusted survival rates for initial transplants of $79 \%$ at 1 year and $52 \%$ at 5 years as published by Christie et al [4].

\section{Conclusions}

For lung transplant recipients, BOS remains to be the primary cause of mortality after the first year. In the current lung allocation score era of lung transplantation, recipients have significantly fewer BOS-free days after 3year follow-up [95]. Further research is needed to better define the pathophysiologic mechanisms in BOS in order to either prevent or delay onset of the disorder. The therapies available for BOS currently are very limited and serve only to slow the decline in pulmonary function. Lung retransplantation continues to be controversial, but survival rates have improved in patients with BOS over the past decade and thus should be considered as a treatment option in this patient population.

\section{List of Abbreviations}

A list of abbreviations used in this manuscript in alphabetical order are: (BOS): bronchiolitis obliterans syndrome; (BAL): bronchoalveolar; (COPD): chronic obstructive pulmonary disease; (CMV): Cytomegalovirus; (EBV): Epstein-Barr virus; $\left(\mathrm{FEF}_{25-75 \%}\right)$ : forced expiratory flow during the middle half of the forced vital capacity; $\left(\mathrm{FEV}_{1}\right)$ : forced expiratory volume in 1 second; (GE): gastroesophageal; (HRCT): high resolution computed tomography; (ISHLT): International Society for Heart and Lung Transplant; (OB): obliterative bronchiolitis; and (TBB): transbronchial biopsies.

\section{Authors' contributions}

The author of this manuscript completed the literature review and developed the manuscript without assistance. There were no contributors in the preparation and development of this manuscript. No funding was required to complete this work.

\section{Competing interests}

The author declares that they have no competing interests.

Received: 24 February 2011 Accepted: 18 July 2011

Published: 18 July 2011

\section{References}

1. Hopkins PM, Aboyoun CL, Chhajed PN, Malouf MA, Plit ML, Rainer SP, Glanville AR: Prospective analysis of 1,235 transbronchial lung biopsies in lung transplant recipients. J Heart Lung Transplant 2002, 21:1062-7.

2. Arcasoy SM, Kotloff RM: Lung transplantation. N Engl J Med 1999, 340:1081-91.

3. Verleden GM: Chronic allograft rejection (obliterative bronchiolitis). Semin Respir Crit Care Med 2001, 22:551-8. 
4. Christie JD, Edwards LB, Kucheryavaya AY, Aurora P, Dobbels F, Kirk R, Rahmel AO, Stehlik J, Hertz MI: The Registry of the International Society for Heart and Lung Transplantation: twenty-seventh official adult lung and heart-lung transplant report-2010. J Heart Lung Transplant 2010, 29:1104-18.

5. Estenne M, Maurer JR, Boehler A, Egan JJ, Frost A, Hertz M, Mallory GB, Snell Gl, Yousem S: Bronchiolitis obliterans syndrome 2001: an update of the diagnostic criteria. J Heart Lung Transplant 2002, 21:297-310.

6. Estenne $M$, Hertz Ml: Bronchiolitis obliterans after human lung transplantation. Am J Respir Crit Care Med 2002, 166:440-4.

7. Yousem SA, Berry GJ, Cagle PT, Chamberlain D, Husain AN, Hruban RH, Marchevsky A, Ohori NP, Ritter J, Stewart S, Tazelaar HD: Revision of the 1990 working formulation for the classification of pulmonary allograft rejection: Lung Rejection Study Group. J Heart Lung Transplant 1996, $15: 1-15$

8. Stewart S, Fishbein MC, Snell GI, Berry GJ, Boehler A, Burke MM, Glanville A, Gould FK, Magro C, Marboe CC, McNeil KD, Reed EF, Reinsmoen NL, Scott JP, Studer SM, Tazelaar HD, Wallwork JL, Westall G, Zamora MR, Zeevi A, Yousem SA: Revision of the 1996 working formulation for the standardization of nomenclature in the diagnosis of lung rejection. $J$ Heart Lung Transplant 2007, 26:1229-42.

9. Heng D, Sharples LD, MCNeil K, Stewart S, Wreghitt T, Wallwork J: Bronchiolitis obliterans syndrome: incidence, natural history, prognosis, and risk factors. J Heart Lung Transplant 1998, 17:1255-63.

10. Verleden GM, Dupont LJ, Van Raemdonck DE: Is it bronchiolitis obliterans syndrome or is it chronic rejection: a reappraisal? Eur Respir J 2005, 25:221-4.

11. Burton CM, Carlsen J, Mortensen J, Andersen CB, Milman N, Iversen M: Long-term survival after lung transplantation depends on development and severity of bronchiolitis obliterans syndrome. J Heart Lung Transplant 2007, 26:681-6.

12. Yousem SA, Duncan SR, Griffith BP: Interstitial and airspace granulation tissue reactions in lung transplant recipients. Am J Surg Pathol 1992, 16:877-84

13. Cooper JD, Billingham M, Egan T, Hertz MI, Higenbottam T, Lynch J, Mauer J, Paradis I, Patterson GA, Smith C, Trulock EP, Vreim C, Yousem S: A working formulation for the standardization of nomenclature and for clinical staging of chronic dysfunction in lung allografts. International Society for Heart and Lung Transplantation. J Heart Lung Transplant 1993, 12:713-6.

14. Jackson $\mathrm{CH}$, Sharples LD, McNeil K, Stewart S, Wallwork J: Acute and chronic onset of bronchiolitis obliterans syndrome (BOS): are they different entities? J Heart Lung Transplant 2002, 21:658-66.

15. Knoop C, Estenne M: Acute and chronic rejection after lung transplantation. Semin Respir Crit Care Med 2006, 27:521-33.

16. Lama VN, Murray S, Lonigro RJ, Toews GB, Chang A, Lau C, Flint A, Chan KM, Martinez FJ: Course of FEV(1) after onset of bronchiolitis obliterans syndrome in lung transplant recipients. Am J Respir Crit Care Med 2007, 175:1192-8.

17. de Jong PA, Dodd JD, Coxson HO, Storness-Bliss C, Paré PD, Mayo JR, Levy RD: Bronchiolitis obliterans following lung transplantation: early detection using computed tomographic scanning. Thorax 2006, 61:799-804.

18. Bankier AA, Van Muylem A, Knoop C, Estenne M, Gevenois PA: Bronchiolitis obliterans syndrome in heart-lung transplant recipients: diagnosis with expiratory CT. Radiology 2001, 218:533-9.

19. Boehler A, Kesten S, Weder W, Speich R: Bronchiolitis obliterans after lung transplantation: a review. Chest 1998, 114:1411-26.

20. Girgis RE, Tu I, Berry GJ, Reichenspurner H, Valentine VG, Conte JV, Ting A, Johnstone I, Miller J, Robbins RC, Reitz BA, Theodore J: Risk factors for the development of obliterative bronchiolitis after lung transplantation. $J$ Heart Lung Transplant 1996, 15:1200-8.

21. Kroshus TJ, Kshettry VR, Savik K, John R, Hertz MI, Bolman RM: Risk factors for the development of bronchiolitis obliterans syndrome after lung transplantation. J Thorac Cardiovasc Surg 1997, 114:195-202.

22. Husain AN, Siddiqui MT, Holmes EW, Chandrasekhar AJ, McCabe M, Radvany R, Garrity ER: Analysis of risk factors for the development of bronchiolitis obliterans syndrome. Am J Respir Crit Care Med 1999, 159:829-33.
23. Sharples LD, McNeil K, Stewart S, Wallwork J: Risk factors for bronchiolitis obliterans: a systematic review of recent publications. J Heart Lung Transplant 2002, 21:271-81

24. Corris PA: Lung transplantation. Bronchiolitis obliterans syndrome. Chest Surg Clin N Am 2003, 13(3):543-557.

25. Burton CM, Iverson M, Carlsen J, Mortesen J, Anderson CB, Steinbrüchel D Scheike T: Acute cellular rejection is a risk factor for bronchiolitis obliterans syndrome independent of post-transplant baseline FEV1. J Heart Lung Transplant 2009, 28(9):888-893.

26. Hachem RR, Khalifah AP, Chakinala MM, Yusen RD, Aloush AA, Mohanakumar T, Patterson GA, Trulock EP, Walter MJ: The significance of a single episode of minimal acute rejection after lung transplantation. Transplantation 2005, 80:1406-13.

27. Valentine VG, Gupta MR, Walker JE Jr, Seoane L, Bonvillain RW, Lombard GA, Weill D, Dhillon GS: Effect of etiology and timing of respiratory tract infections on development of bronchiolitis obliterans syndrome. J Heart Lung Transplant 2009, 28:163-9.

28. Kotsimbos TC, Snell Gl, Levvey B, Spelman DW, Fuller AJ, Wesselingh SL, Williams TJ, Ostergaard L: Chlamydia pneumoniae serology in donors and recipients and the risk of bronchiolitis obliterans syndrome after lung transplantation. Transplantation 2005, 79:269-75

29. Weigt SS, Elashoff RM, Huang C, Ardehali A, Gregson AL, Kubak B, Fishbein MC, Saggar R, Keane MP, Saggar R, Lynch JP, Zisman DA, Ross DJ, Belperio JA: Aspergillus Colonization of the Lung Allograft Is a Risk Factor for Bronchiolitis Obliterans Syndrome. Am J Transplant 2009, 9:1903-11

30. McManus TE, Milne DG, Whyte KF, Wilsher ML: Exudative bronchiolitis after lung transplantation. J Heart Lung Transplant 2008, 27:276-81.

31. Hadjiliadis D, Chaparro C, Gutierrez C, Steele MP, Singer LG, Davis RD, Waddell TK, Hutcheon MA, Palmer SM, Keshavjee S: Impact of lung transplant operation on bronchiolitis obliterans syndrome in patients with chronic obstructive pulmonary disease. Am J Transplant 2006, 6:183-9.

32. Vilchez RA, Dauber J, McCurry K, lacono A, Kusne S: Parainfluenza virus infection in adult lung transplant recipients: an emergent clinical syndrome with implications on allograft function. Am J Transplant 2003, 3:116-20.

33. Kumar D, Erdman D, Keshavjee S, Peret T, Tellier R, Hadjiliadis D, Johnson G, Ayers M, Siegal D, Humar A: Clinical impact of community-acquired respiratory viruses on bronchiolitis obliterans after lung transplant. Am J Transplant 2005, 5:2031-6.

34. Khalifah AP, Hachem RR, Chakinala MM, Schechtman KB, Patterson GA, Schuster DP, Mohanakumar T, Trulock EP, Walter MJ: Respiratory viral infections are a distinct risk for bronchiolitis obliterans syndrome and death. Am J Respir Crit Care Med 2004, 170:181-7.

35. Neurohr C, Huppmann P, Leuchte H, Schwaiblmair M, Bittmann I, Jaeger G, Hatz R, Frey L, Uberfuhr P, Reichart B, Behr J: Munich Lung Transplant Group. Human herpesvirus 6 in bronchalveolar lavage fluid after lung transplantation: a risk factor for bronchiolitis obliterans syndrome? Am J Transplant 2005, 5:2982-91.

36. Glanville AR, Scott Al, Morton JM, Aboyoun CL, Plit ML, Carter IW, Malouf MA: Intravenous ribavirin is a safe and cost-effective treatment for respiratory syncytial virus infection after lung transplantation. J Heart Lung Transplant 2005, 24:2114-9.

37. Keenan RJ, Lega ME, Dummer JS, Paradis IL, Dauber JH, Rabinowich $H$, Yousem SA, Hardesty RL, Griffith BP, Duquesnoy RJ, Zeevi A: Cytomegalovirus serologic status and postoperative infection correlated with risk of developing chronic rejection after pulmonary transplantation. Transplantation 1991, 51:433-8.

38. Smith MA, Sundaresan S, Mohanakumar T, Trulock EP, Lynch JP, Phelan DL, Cooper JD, Patterson GA: Effect of development of antibodies to HLA and cytomegalovirus mismatch on lung transplantation survival and development of bronchiolitis obliterans syndrome. J Thorac Cardiovasc Surg 1998, 116:812-20.

39. Tamm M, Aboyoun CL, Chhajed PN, Rainer S, Malouf MA, Glanville AR: Treated cytomegalovirus pneumonia is not associated with bronchiolitis obliterans syndrome. Am J Respir Crit Care Med 2004, 170:1120-3.

40. Engelmann I, Welte T, Fühner T, Simon AR, Mattner F, Hoy L, Schulz TF, Gottlieb J: Detection of Epstein-Barr virus DNA in peripheral blood is 
associated with the development of bronchiolitis obliterans syndrome after lung transplantation. J Clin Virol 2009, 45:47-53.

41. Fiser SM, Tribble CG, Long SM, Kaza AK, Kern JA, Jones DR, Robbins MK, Kron IL: Ischemia-reperfusion injury after lung transplantation increases risk of late bronchiolitis obliterans syndrome. Ann Thorac Surg 2002, 73:1041-7.

42. Whitson BA, Prekker ME, Herrington CS, Whelan TP, Radosevich DM Hertz MI, Dahlberg PS: Primary graft dysfunction and long-term pulmonary function after lung transplantation. I Heart Lung Transplant 2007, 26:1004-11.

43. Daud SA, Yusen RD, Meyers BF, Chakinala MM, Walter MJ, Aloush AA, Patterson GA, Trulock EP, Hachem RR: Impact of immediate primary lung allograft dysfunction on bronchiolitis obliterans syndrome. Am J Respir Crit Care Med 2007, 175:507-13.

44. D'Ovidio F, Mura M, Tsang M, Waddell TK, Hutcheon MA, Singer LG, Hadjiliadis D, Chaparro C, Gutierrez C, Pierre A, Darling G, Liu M, Keshavjee S: Bile acid aspiration and the development of bronchiolitis obliterans after lung transplantation. J Thorac Cardiovasc Surg 2005, 129:1144-52.

45. Blondeau K, Mertens V, Vanaudenaerde BA, Verleden GM, Van Raemdonck DE, Sifrim D, Dupont LJ: Gastro-oesophageal reflux and gastric aspiration in lung transplant patients with or without chronic rejection. Eur Respir J 2008, 31:707-13.

46. Davis RD Jr, Lau CL, Eubanks S, Messier RH, Hadjiliadis D, Steele MP, Palmer SM: Improved lung allograft function after fundoplication in patients with gastroesophageal reflux disease undergoing lung transplantation. J Thorac Cardiovasc Surg 2003, 125:533-42.

47. Cantu E, Appel JZ, Hartwig MG, Woreta H, Green C, Messier R, Palmer SM, Davis RD Jr: J. Maxwell Chamberlain Memorial Paper. Early fundoplication prevents chronic allograft dysfunction in patients with gastroesophageal reflux disease. Ann Thorac Surg 2004, 78:1142-51

48. Palmer SM, Davis RD, Hadjiliadis D, Hertz Ml, Howell DN, Ward FE, Savik K, Reinsmoen NL: Development of an antibody specific to major histocompatibility antigens detectable by flow cytometry after lung transplant is associated with bronchiolitis obliterans syndrome. Transplantation 2002, 74:799-804.

49. Girnita AL, Duquesnoy R, Yousem SA, lacono AT, Corcoran TE, Buzoianu M, Johnson B, Spichty KJ, Dauber JH, Burckart G, Griffith BP, McCurry KR, Zeevi A: HLA-specific antibodies are risk factors for lymphocytic bronchiolitis and chronic lung allograft dysfunction. Am J Transplant 2005, 5:131-8

50. Schulman LL, Weinberg AD, McGregor C, Galantowicz ME, Suciu-Foca NM, Itescu S: Mismatches at the HLA-DR and HLA-B loci are risk factors for acute rejection after lung transplantation. Am J Respir Crit Care Med 1998, 157:1833-7.

51. van den Berg JW, Hepkema BG, Geertsma A, Koëter GH, Postma DS, de Boer WJ, Lems SP, van der Bij W: Long-term outcome of lung transplantation is predicted by the number of HLA-DR mismatches. Transplantation 2001, 71:368-73.

52. Quantz MA, Bennett LE, Meyer DM, Novick RJ: Does human leukocyte antigen matching influence the outcome of lung transplantation? An analysis of 3,549 lung transplantations. J Heart Lung Transplant 2000, 19:473-9.

53. Sumpter TL, Wilkes DS: Role of autoimmunity in organ allograft rejection: a focus on immunity to type $V$ collagen in the pathogenesis of lung transplant rejection. Am J Physiol Lung Cell Mol Physiol 2004, 286:L1129-39.

54. Cairn J, Yek T, Banner NR, Khaghani A, Hodson ME, Yacoub M: Time-related changes in pulmonary function after conversion to tacrolimus in bronchiolitis obliterans syndrome. J Heart Lung Transplant 2003, 22:50-7.

55. Whyte RI, Rossi SJ, Mulligan MS, Florn R, Baker L, Gupta S, Martinez FJ, Lynch JP: Mycophenolate mofetil for obliterative bronchiolitis syndrome after lung transplantation. Ann Thorac Surg 1997, 64:945-8.

56. Hachem RR, Yusen RD, Chakinala MM, Meyers BF, Lynch JP, Aloush AA, Patterson GA, Trulock EP: A randomized controlled trial of tacrolimus versus cyclosporine after lung transplantation. $J$ Heart Lung Transplant 2007, 26:1012-8.

57. Revell MP, Lewis ME, Llewellyn-Jones CG, Wilson IC, Bonser RS: Conservation of small-airway function by tacrolimus/cyclosporine conversion in the management of bronchiolitis obliterans following lung transplantation. J Heart Lung Transplant 2000, 19:1219-23.
58. Verleden GM, Dupont $L$, Van Raemdonck D, Vanhaecke J: Effect of switching from cyclosporine to tacrolimus on exhaled nitric oxide and pulmonary function in patients with chronic rejection after lung transplantation. J Heart Lung Transplant 2003, 22:908-13.

59. lacono AT, Johnson BA, Grgurich WF, Youssef JG, Corcoran TE, Seiler DA, Dauber JH, Smaldone GC, Zeevi A, Yousem SA, Fung JJ, Burckart GJ, McCurry KR, Griffith BP: A randomized trial of inhaled cyclosporine in lung-transplant recipients. N Engl J Med 2006, 354:141-50.

60. Groves S, Galazka M, Johnson B, Corcoran T, Verceles A, Britt E, Todd N, Griffith B, Smaldone GC, lacono A: Inhaled cyclosporine and pulmonary function in lung transplant recipients. J Aerosol Med Pulm Drug Deliv 2010, 23:31-9.

61. lacono AT, Corcoran TE, Griffith BP, Grgurich WF, Smith DA, Zeevi A, Smaldone GC, McCurry KR, Johnson BA, Dauber JH: Aerosol cyclosporin therapy in lung transplant recipients with bronchiolitis obliterans. Eur Respir J 2004, 23:384-90.

62. Hayes D Jr, Zwischenberger JB, Mansour HM: Aerosolized tacrolimus: a case report in a lung transplant recipient. Transplant Proc 2010, 42:3876-9.

63. Reams BD, Musselwhite LW, Zaas DW, Steele MP, Garantziotis S, Eu PC, Snyder LD, Curl J, Lin SS, Davis RD, Palmer SM: Alemtuzumab in the treatment of refractory acute rejection and bronchiolitis obliterans syndrome after human lung transplantation. Am J Transplant 2007, 7:2802-8.

64. Gerhardt SG, McDyer JF, Girgis RE, Conte JV, Yang SC, Orens JB: Maintenance azithromycin therapy for bronchiolitis obliterans syndrome: results of a pilot study. Am J Respir Crit Care Med 2003, 168:121-5.

65. Verleden GM, Dupont LJ: Azithromycin therapy for patients with bronchiolitis obliterans syndrome after lung transplantation. Transplantation 2004, 77:1465-7.

66. Yates B, Murphy DM, Forrest IA, Ward C, Rutherford RM, Fisher AJ, Lordan JL, Dark JH, Corris PA: Azithromycin reverses airflow obstruction in established bronchiolitis obliterans syndrome. Am J Respir Crit Care Med 2005, 172:772-5.

67. Gottlieb J, Szangolies J, Koehnlein T, Golpon H, Simon A, Welte T: Longterm azithromycin for bronchiolitis obliterans syndrome after lung transplantation. Transplantation 2008, 85:36-41.

68. Neurohr C, Huppmann P, Samweber B, Leuschner S, Zimmermann G, Leuchte H, Baumgartner R, Hatz R, Frey L, Ueberfuhr P, Bittmann I, Behr J, Munich Lung Transplant Group: Prognostic value of bronchoalveolar lavage neutrophilia in stable lung transplant recipients. J Heart Lung Transplant 2009, 28:468-74.

69. Johnson BA, lacono AT, Zeevi A, McCurry KR, Duncan SR: Statin use is associated with improved function and survival of lung allografts. Am J Respir Crit Care Med 2003, 167:1271-8.

70. O'Hagan AR, Stillwell PC, Arroliga A, Koo A: Photopheresis in the treatment of refractory bronchiolitis obliterans complicating lung transplantation. Chest 1999, 115:1459-62.

71. Salerno CT, Park SJ, Kreykes NS, Kulick DM, Savik K, Hertz MI, Bolman RM: Adjuvant treatment of refractory lung transplant rejection with extracorporeal photopheresis. J Thorac Cardiovasc Surg 1999, 117:1063-9.

72. Meloni F, Cascina A, Miserere S, Perotti C, Vitulo P, Fietta AM: Peripheral CD4(+)CD25(+) TREG cell counts and the response to extracorporeal photopheresis in lung transplant recipients. Transplant Proc 2007, 39:213-7.

73. George JF, Gooden CW, Guo L, Kirklin JK: Role for CD4(+)CD25(+) T cells in inhibition of graft rejection by extracorporeal photopheresis. J Heart Lung Transplant 2008, 27:616-22.

74. Benden C, Speich R, Hofbauer GF, Irani S, Eich-Wanger C, Russi EW, Weder W, Boehler A: Extracorporeal photopheresis after lung transplantation: a 10-year single-center experience. Transplantation 2008, 86:1625-7.

75. Morrell MR, Despotis GJ, Lublin DM, Patterson GA, Trulock EP, Hachem RR: The efficacy of photopheresis for bronchiolitis obliterans syndrome after lung transplantation. J Heart Lung Transplant 2010, 29:424-31.

76. Lee JC, Christie JD, Keshavjee S: Primary graft dysfunction: definition, risk factors, short- and long-term outcomes. Semin Respir Crit Care Med 2010, 31:161-71.

77. Jain R, Hachem RR, Morrell MR, Trulock EP, Chakinala MM, Yusen RD, Huang HJ, Mohanakumar T, Patterson GA, Walter MJ: Azithromycin is associated with increased survival in lung transplant recipients with bronchiolitis obliterans syndrome. J Heart Lung Transplant 2010, 29:531-7. 
78. Siegel MJ, Bhalla S, Gutierrez FR, Hildebolt C, Sweet S: Post-lung transplantation bronchiolitis obliterans syndrome: usefulness of expiratory thin-section CT for diagnosis. Radiology 2001, 220:455-62.

79. Choi YW, Rossi SE, Palmer SM, DeLong D, Erasmus JJ, McAdams HP: Bronchiolitis obliterans syndrome in lung transplant recipients: correlation of computed tomography findings with bronchiolitis obliterans syndrome stage. J Thorac Imaging 2003, 18:72-9.

80. Miller WT Jr, Kotloff RM, Blumenthal NP, Aronchick JM, Gefter WB, Miller WT: Utility of high resolution computed tomography in predicting bronchiolitis obliterans syndrome following lung transplantation: preliminary findings. J Thorac Imaging 2001, 16:76-80.

81. Konen E, Gutierrez C, Chaparro C, Murray CP, Chung T, Crossin J, Hutcheon MA, Paul NS, Weisbrod GL: Bronchiolitis obliterans syndrome in lung transplant recipients: can thin-section $\mathrm{CT}$ findings predict disease before its clinical appearance? Radiology 2004, 231:467-73.

82. Verleden GM, Vanaudenaerde BM, Dupont LJ, Van Raemdonck DE: Azithromycin reduces airway neutrophilia and interleukin-8 in patients with bronchiolitis obliterans syndrome. Am J Respir Crit Care Med 2006, 174:566-70

83. Vos R, Blondeau K, Vanaudenaerde BM, Mertens V, Van Raemdonck DE, Sifrim D, Dupont $L$, Verleden GM: Airway colonization and gastric aspiration after lung transplantation: do birds of a feather flock together? J Heart Lung Transplant 2008, 27:843-9.

84. Vos R, Vanaudenaerde BM, Geudens N, Dupont L, Van Raemdonck DE, Verleden GM: Pseudomonal airway colonisation: risk factor for bronchiolitis obliterans syndrome after lung transplantation? Eur Respir J 2008, 31:1037-45.

85. Botha P, Archer L, Anderson RL, Lordan J, Dark JH, Corris PA, Gould K, Fisher AJ: Pseudomonas aeruginosa colonization of the allograft after lung transplantation and the risk of bronchiolitis obliterans syndrome. Transplantation 2008, 85:771-4.

86. Novick RJ, Schäfers HJ, Stitt L, Andréassian B, Klepetko W, Hardesty RL, Frost A: Patterson GA Seventy-two pulmonary retransplantations for obliterative bronchiolitis: predictors of survival. Ann Thorac Surg 1995, 60:111-6.

87. Novick RJ, Schäfers HJ, Stitt L, Andréassian B, Duchatelle JP, Klepetko W, Hardesty RL, Frost A, Patterson GA: Recurrence of obliterative bronchiolitis and determinants of outcome in 139 pulmonary retransplant recipients. J Thorac Cardiovasc Surg 1995, 110:1402-13, discussion 1413-4.

88. Novick RJ, Stitt LW, Al-Kattan K, Klepetko W, Schäfers HJ, Duchatelle JP, Khaghani A, Hardesty RL, Patterson GA, Yacoub MH: Pulmonary retransplantation: predictors of graft function and survival in 230 patients. Pulmonary Retransplant Registry. Ann Thorac Surg 1998, 65:227-34

89. Kawut SM, Lederer DJ, Keshavjee S, Wilt JS, Daly T, D'Ovidio F, Sonett JR, Arcasoy SM, Barr ML: Outcomes after lung retransplantation in the modern era. Am J Respir Crit Care Med 2008, 177(1):114-20.

90. Brugière O, Thabut G, Castier Y, Mal H, Dauriat G, Marceau A, Lesèche G: Lung retransplantation for bronchiolitis obliterans syndrome: long-term follow-up in a series of 15 recipients. Chest 2003, 123:1832-7.

91. Martinu T, Howell DN, Davis RD, Steele MP, Palmer SM: Pathologic correlates of bronchiolitis obliterans syndrome in pulmonary retransplant recipients. Chest 2006, 129:1016-23.

92. Strueber M, Fischer S, Gottlieb J, Simon AR, Goerler H, Gohrbandt B, Welte $\mathrm{T}$, Haverich A: Long-term outcome after pulmonary retransplantation. J Thorac Cardiovasc Surg 2006, 132:407-12.

93. Aigner C, Jaksch P, Taghavi S, Lang G, Reza-Hoda MA, Wisser W, Klepetko W: Pulmonary retransplantation: is it worth the effort? A longterm analysis of 46 cases. J Heart Lung Transplant 2008, 27:60-5.

94. Osaki S, Maloney JD, Meyer KC, Cornwell RD, Edwards NM, De Oliveira NC: Redo lung transplantation for acute and chronic lung allograft failure: long-term follow-up in a single center. Eur J Cardiothorac Surg 2008, 34:1191-7.

95. Emaminia A, Hennessy SA, Hranjec T, Lapar DJ, Kozower BD, Jones DR, Kron IL, Lau CL: Bronchiolitis obliterans syndrome occurs earlier in the post-lung allocation score era. J Thorac Cardiovasc Surg 2011, 141:1278-82.

doi:10.1186/1749-8090-6-92

Cite this article as: Hayes: A review of bronchiolitis obliterans syndrome and therapeutic strategies. Journal of Cardiothoracic Surgery 2011 6:92.

\section{Submit your next manuscript to BioMed Central and take full advantage of:}

- Convenient online submission

- Thorough peer review

- No space constraints or color figure charges

- Immediate publication on acceptance

- Inclusion in PubMed, CAS, Scopus and Google Scholar

- Research which is freely available for redistribution 